\title{
Paweł Bronowski
}

Instytut Psychologii, Akademia Pedagogiki Specjalnej w Warszawie

\author{
Jacek Bednarzak
}

Grupa Wsparcia Osób z Doświadczeniem Kryzysu Psychicznego TROP, Akademia Pedagogiki Specjalnej w Warszawie

\section{GRUPA WSPARCIA TROP - PIĘĆ LAT DOŚWIADCZEŃ}

\begin{abstract}
Support Group for Persons with Mental Crisis Experience TROP - five years of experience

Support Group for Persons with Mental Crisis Experience TROP consist of people with mental disease experience. The group is based in Warsaw. It started in 2013. Regular meetings are held in the Academy of Special Education. Among TROP's actions are lessons for high school students, school pupils and clerks focused on breaking stereotypes about persons with mental illness. TROP offers support in difficult situations and give telephone counselling for persons with mental crisis experience.The group provides mutual support by systematic meetings, researches the condition of psychiatric services and presents in various affairs (conferences, workshops).
\end{abstract}

Key words: self-help, persons with mental health experience, support groups

\section{Ruch samopomocowy osób z doświadczeniem chorób psychicznych}

Działająca od 2013 roku Grupa Wsparcia TROP stanowi jedną z nielicznych w Polsce inicjatyw samopomocowych stworzonych przez osoby z doświadczeniem choroby psychicznej. Specyfika Grupy polega przede wszystkim na jej całkowitej niezależności od systemu leczenia psychiatrycznego i pełnej samodzielności zarówno w wyborze celów, jak i sposobie ich osiągania. Grupa współpracuje z Akademią Pedagogiki Specjalnej, która oferuje jej miejsce do spotkań, przyjazną atmosferę oraz możliwość wsparcia merytorycznego przy realizacji programów.

Grupy samopomocowe osób chorujących psychicznie są w krajach Europy Zachodniej i Stanach Zjednoczonych popularne i liczne. Ich intensywny rozwój należy wiązać przede wszystkim z tezami antypsychiatrii oraz koncepcją procesu zdrowienia. Antypsychiatria, czyli ruch ideowy z lat sześćdziesiątych i siedemdziesiątych XX wieku, znacząco zmieniła sposób rozumienia istoty chorób psychicznych i wpłynęła na sytuację osób chorujących. Sprzeciw wobec stygmatyzacji i etykietowaniu chorych (Goffman 2005; 
Scheff 1966) oraz przyjęcie społecznej, a nie jedynie biologicznej perspektywy etiologii chorób psychicznych (Laing 1967) doprowadziły do istotnych zmian. Dotyczyły one postaw społecznych wobec osób doświadczających zaburzeń psychicznych (Szasz 1960) oraz negacji obowiązującego wówczas azylowego modelu ich leczenia (Goffman 2011). W ówczesnych placówkach leczniczych i opiekuńczych dostrzegano przede wszystkim instytucje totalne, niszczące indywidualność i łamiące prawa człowieka. Ściśle biologiczny i zdehumanizowany model leczenia został poddany fundamentalnej krytyce i ostatecznie zmieniony. Osoby chorujące, pełniące dotąd wyłącznie rolę biernych odbiorców zabiegów psychiatrycznych, uzyskały realną szansę na wyrwanie się z roli „wiecznego pacjenta". Zaowocowało to powstawaniem niezależnych grup samopomocowych, często nastawionych wobec psychiatrii niechętnie.

Kolejnym impulsem wzmacniającym ruch samopomocowy osób chorujących była późniejsza w stosunku do antypsychiatrii, wywodząca się ze środowiska osób z doświadczeniem kryzysu psychicznego, koncepcja „procesu zdrowienia”. Życie osób chorujących jest w niej postrzegane w kontekście zdrowienia, zasobów i możliwie satysfakcjonującego funkcjonowania (Anthony 1993). Idea „wspierania procesu zdrowienia” odwołuje się do samodzielności i aktywności osób doświadczających zaburzeń psychicznych, zakładając, że ich życie nie wiąże się jedynie z objawami, leczeniem psychiatrycznym, farmakoterapią i hospitalizacjami. Te elementy oczywiście występują, lecz dla procesu zdrowienia szczególnie istotne są kwestie związane z samodzielnością, odzyskiwaniem podmiotowości i działaniem na rzecz innych. W tym ujęciu zdrowienie ściśle wiąże się z dystansowaniem od psychiatrycznej etykiety, budowaniem sieci kontaktów społecznych oraz zaangażowaniem w pomaganie innym (Lysaker, Cambell, Johanessen 2005; Deegan 1996).

Ruch samopomocowy w Europie Zachodniej i Stanach Zjednoczonych działa od wielu już lat, jest pozytywnie odbierany społecznie, stanowi ważny element w systemie wsparcia. Wpływa bezpośrednio zarówno na sytuację osób chorujących, jak i na postawy społeczne wobec nich. Jest dość zróżnicowany, jeśli chodzi o zakres działania. Do najczęściej realizowanych obecnie zadań można zaliczyć: prowadzenie grup zorientowanych na zdrowienie, udzielanie porad i wsparcia innym chorującym, edukację społeczną oraz interwencje w zakresie praw człowieka (Repper, Carter 2011).

W świetle wyników badań dotyczących uczestnictwa w ruchu samopomocowym w kontekście procesu zdrowienia można uznać, że ma on jednoznacznie pozytywny wpływ na jego parametry. Stwierdzono, że u uczestników poprawiają się: samoocena, poczucie przydatności i sprawstwa oraz indywidualna sieć wsparcia. Z badań wynika również, że osoby zaangażowane w samopomoc rzadziej niż nieuczestniczący w niej doświadczają rehospitalizacji (Omeni et al. 2014).

Popularność ruchu samopomocowego w krajach Europy Zachodniej oraz Stanach Zjednoczonych można więc wyjaśniać zarówno w kontekście jego społecznej przydatności, jak i pozytywnego wpływu na samopoczucie osób chorujących psychicznie, będących jego uczestnikami (Ion, Beer 2003). Ruch samopomocowy jest ważnym elementem systemu wsparcia oraz czynnikiem pozytywnie wpływającym na zapobieganie stygmatyzującym postawom społecznym. Przyczynił się do przemian w systemach opieki psychiatrycznej. 
W Polsce ruch ten znajduje się w początkowym stadium tworzenia. Nie sprzyjają mu generalnie ani trudna sytuacja społeczna osób chorujących, ani brak przestrzeni na samodzielność oraz, co wydaje się szczególnie istotne, nadal popularne w naszym kraju obsadzenie osób doświadczających zaburzeń psychicznych w roli „wiecznego pacjenta psychiatrycznego". Wąskie ramy funkcjonowania wyznaczone przez tę rolę sprowadzają osoby chorujące do biernego odbiorcy świadczeń medycznych realizowanych w paternalistycznie zorientowanym systemie lecznictwa psychiatrycznego. Co więcej, nadal dominujący w Polsce azylowy model leczenia jest odległy od idei promowania samodzielności i niezależności u swoich pacjentów. Wszystko to powoduje, że ruch samopomocowy osób chorujących psychicznie w Polsce nie jest popularny. Realnie działające grupy można policzyć na palcach jednej ręki. Ich popularności i rozwojowi nie sprzyjają stygmatyzujące nastawienia społeczne ani też azylowy model leczenia.

Jedną z nielicznych grup samopomocowych działających, jak na polskie warunki, od długiego już czasu, jest Grupa Wsparcia Osób z Doświadczeniem Kryzysu Psychicznego TROP. Powstała w 2013 roku, w jej skład wchodzą osoby chorujące przede wszystkim na schizofrenię. Grupa działa pod patronatem Wydziału Stosowanych Nauk Społecznych Akademii Pedagogiki Specjalnej. Dzięki tej afiliacji Grupa jest niezależna i samodzielna. Pozostaje oddalona od wpływu zarówno lecznictwa psychiatrycznego, jak i azylowych instytucji opiekuńczych. Dzięki temu możliwe jest rzeczywiste partnerstwo we współdziałaniu uczelni i członków Grupy. Akademia zapewnia przede wszystkim miejsce do regularnych spotkań oraz przyjazną atmosferę. Członkowie Grupy mogą również liczyć na wsparcie eksperckie ze strony Instytutu Psychologii APS przy realizowanych projektach. Warto również wspomnieć o pomocy, jaką Grupa otrzymuje od studentów Akademii, szczególnie ze Studenckiego Naukowego Koła Psychologii Klinicznej i Psychoterapii APSI. Wspierają oni Grupę między innymi poprzez pomoc w organizacji spotkań oraz prowadzonych programach.

Działająca od pięciu lat Grupa charakteryzuje się przede wszystkim dużą stabilnością swoich poczynań. Liczba odbywających się w Akademii Pedagogiki Specjalnej comiesięcznych spotkań wynosi już ponad pięćdziesiąt. Z większości powstały sprawozdania dostępne w bazie dokumentującej działania Grupy (dostępne na stronie www.czasnaporozumienie.pl). Regularne spotkania stały się cennym doświadczeniem zarówno dla Grupy TROP, jak i dla społeczności Akademii.

Działalność TROP-u nie ogranicza się do comiesięcznych spotkań. Realizowane przez Grupę projekty są liczne i zróżnicowane. Zostały zaprezentowane w dalszej części tekstu. Warto zwrócić uwagę na trzy z nich, które mogą być uznane za szczególnie ważne dla rozwoju Grupy. Pierwszym z nich jest zrealizowane w roku 2014 szkolenie „Edukator Praw Obywatelskich”. Zostało ono przeprowadzone przez Biuro Rzecznika Praw Obywatelskich. Grupa TROP uczestniczyła w przygotowaniu założeń szkolenia oraz wzięła w nim udział. Szkolenie to zapoczątkowało współpracę Grupy z Rzecznikiem Praw Obywatelskich w kolejnych latach. Pokazało również, że Rzecznik może być dla niezależnych środowisk osób chorujących wyjątkowo ważnym sojusznikiem. Drugim projektem, szczególnie istotnym z uwagi na swój nowatorski w warunkach polskich 
charakter jest „Doradca Telefoniczny”. W jego ramach członkowie Grupy, nieprzerwanie od 2015 roku, udzielają porad telefonicznych innym osobom chorującym i członkom ich rodzin. Jest to jedyny tego rodzaju program w Polsce, w którym eksperci przez doświadczenie zapewniają wsparcie osobom potrzebującym pomocy i porady ze strony tych, którzy mają podobne doświadczenia. Dzięki trwającemu już od długiego czasu programowi powstał zespół doradców o sporym doświadczeniu i umiejętnościach. Projektem trzecim, o którym również warto wspomnieć, jest coaching Grupy, jaki w latach 2016-2017 zapewniło Biuro Obsługi Ruchu Inicjatyw Społecznych Boris. Wsparcie to można uznać za szczególnie ważne dla rozwoju Grupy. Coaching koncentrował się na identyfikacji jej celów, optymalnych sposobach działania oraz współpracy z sojusznikami.

Przez pięć minionych lat TROP zrealizował wiele projektów, najważniejsze z nich zostały opisane w dalszej części artykułu.

\section{Działania Grupy Wsparcia TROP}

Impulsem do powstania Grupy była potrzeba stworzenia organizacji osób chorujących, którzy byliby partnerami profesjonalistów podczas tworzenia programów wsparcia dla osób chorujących psychicznie. Z uwagi na specyfikę tych chorób i brak organizacji skupiającej osoby po kryzysie psychicznym, ich głos był dotychczas mało słyszalny i nie był brany pod uwagę podczas podejmowania decyzji istotnych dla tego środowiska. Trzeba pamiętać, że to właśnie osoby po kryzysie doskonale wiedzą, jak odczuwane są objawy choroby, jakie są działania uboczne przyjmowanych leków i z jakimi trudnościami można spotkać się w codziennym życiu. Dla genezy Grupy ważne było również przekonanie, że osoby, które dobrze radzą sobie z trudnościami życia codziennego, powinny udzielać wsparcia innym chorującym. Działanie w TROP-ie daje możliwość wzajemnej pomocy, wspólnej pracy na rzecz poprawy sytuacji osób chorujących, oferuje pole dla aktywności, poczucie bycia potrzebnym oraz poszerzanie grona przyjaciół i znajomych.

Od 2013 roku w każdym miesiącu Grupa spotyka się regularnie w Akademii Pedagogiki Specjalnej. Zebrania te mają charakter przede wszystkim organizacyjny i informacyjny. Jak już wspomniano, do chwili obecnej odbyło się ponad pięćdziesiąt tego rodzaju spotkań, w których wzięło udział łącznie około osiemdziesięciu osób. Ponadto w 2017 roku zorganizowano dwa spotkania klubowe poświęcone integracji Grupy i pozyskiwaniu nowych członków.

Niezależnie od regularnych zebrań w początkowym okresie działania Grupy odbyły się spotkania szkoleniowe prowadzone przez kadrę naukową Instytutu Psychologii APS. Były to między innymi szkolenia przygotowujące do prelekcji zapobiegających stygmatyzacji (wśród uczniów i studentów) oraz do pełnienia roli Doradców Telefonicznych (sposoby udzielania wsparcia emocjonalnego i informacyjnego innym chorującym).

Członkostwo w TROP-ie nie wiąże się z koniecznością brania udziału we wszystkich podejmowanych przez Grupę inicjatywach. Zarazem jednak każdy z uczestników ma możliwość znalezienia odpowiedniej dla siebie przestrzeni do działania. W spotkaniach 
Grupy często uczestniczą również osoby, które z uwagi na aktualne samopoczucie nie podejmują aktywnego działania, czerpiąc korzyści z przebywania w gronie przyjaźnie nastawionych i chętnych do pomocy osób.

Do najważniejszych realizowanych obecnie (lub już zakończonych) programów należą opisane poniżej.

1. Badanie dotyczące oczekiwań użytkowników wobec psychiatrii i programów wsparcia. Badaniem objęto 69 respondentów po kryzysie psychicznym, w tym 29 kobiet i 40 mężczyzn w wieku od 23 do 74 lat. Ankietowano osoby, które były hospitalizowane i pozostawały pod opieką placówek wsparcia środowiskowego. Badanie zrealizowano metodą wywiadów kwestionariuszowych w okresie od 30 kwietnia do 30 maja 2014 roku w sześciu lokalnych placówkach wsparcia środowiskowego. Było to jedno z pierwszych w Polsce badań przeprowadzonych przez niezależną grupę użytkowników lecznictwa psychiatrycznego. Raport z badania jest dostępny na stronie www.czasnaporozumienie.pl. Wyniki były wielokrotnie prezentowane na konferencjach naukowych.

\section{Program „Doradca Telefoniczny”.}

Program jest realizowany nieprzerwanie od 2015 roku. W jego ramach sześciu członków Grupy zostało przeszkolonych do pełnienia funkcji Doradcy. Dyżurują oni przy telefonie od poniedziałku do czwartku każdego tygodnia. Celem programu jest udzielanie innym chorującym, ich rodzinom i przyjaciołom wsparcia emocjonalnego oraz informacyjnego. Problemy zgłaszane w rozmowach z Doradcami i przebieg udzielonych porad są omawiane na regularnych superwizjach, dzięki czemu są one kompetentne i efektywne. Warto dodać, że wsparcie płynące od ekspertów przez doświadczenie bywa bardziej przekonujące i z uwagi na swój autentyzm jest odbierane z większym zainteresowaniem. Program ten jest szczególnie przydatny dla osób w początkowym stadium choroby lub u osób, które nie rozpoczęły jeszcze leczenia. Porady Doradców są również szczególnie ważne dla osób po kryzysie, opuszczających szpitale psychiatryczne. Doradcy Telefoniczni są wynagradzani za swoją pracę dzięki dofinansowaniu ze strony miasta Warszawy.

3. Kurs „Edukator Praw Obywatelskich” i działania na rzecz ochrony praw człowieka. W 2014 roku członkowie Grupy wzięli udział w szkoleniu organizowanym przez Biuro Rzecznika Praw Obywatelskich. Obejmowało ono szeroko rozumianą problematykę egzekwowania praw obywatelskich. Po zakończeniu kursu przeprowadzono dodatkowe szkolenie dla kilku uczestników Grupy, którzy zdecydowali się krzewić idee praw człowieka w środowisku osób z doświadczeniem kryzysu psychicznego. Podjęły one działalność edukacyjną w warszawskich placówkach wsparcia (m.in. Dom pod Fontanną, Środowiskowe Domy Samopomocy, Warsztaty Terapii Zajęciowej) oraz w szpitalach psychiatrycznych. W trakcie spotkań prezentowane są idee praw człowieka oraz omawiane 
metody ich obrony. Członkowie TROP-u rozpowszechniają również materiały informacyjne Rzecznika Praw Obywatelskich. Uczestnicy spotkań mają ponadto możliwość zgłoszenia przypadków łamania ich praw, a członkowie Grupy okresowo przekazują te materiały Rzecznikowi.

4. Prelekcje destygmatyzacyjne dla uczniów szkół.

Ważnym celem Grupy TROP jest przeciwdziałanie stygmatyzacji oraz szerzenie rzetelnej wiedzy o specyfice chorób psychicznych. W ramach tych działań prowadzone są prelekcje wśród uczniów gimnazjów i liceów. Dzięki nim młodzież szkolna widzi w chorych osoby, które mogą uczyć się, pracować i efektywnie funkcjonować. W ramach tych działań dotychczas przeprowadzono22 prelekcje wśród uczniów warszawskich gimnazjów i liceów. Uczestniczyło w nich łącznie około 550 uczniów.

5. Spotkania edukacyjne dla studentów.

Równolegle z prelekcjami dla młodzieży szkolnej Grupa prowadzi podobne prelekcje dla młodzieży akademickiej. Odbyły się 22 spotkania dla studentów psychologii Akademii Pedagogiki Specjalnej i Uniwersytetu Kardynała Stefana Wyszyńskiego. Łącznie prelekcji wysłuchało ponad 600 osób. Został również przygotowany 15-godzinny wykład fakultatywny dla studentów psychologii. Zostanie on w całości przeprowadzony przez członków Grupy.

6. Spotkania destygmatyzacyjno-informacyjne dla organizacji pozarządowych i instytucji samorządowych.

Dotychczas przeprowadzono pięć tego rodzaju spotkań: dwa dla pracowników Ośrodków Pomocy Społecznej (dzielnice Bemowo i Targówek m.st. Warszawy) oraz trzy spotkania edukacyjne dla wolontariuszy i pracowników w organizacjach pozarządowych (Fundacja ITAKA Centrum Poszukiwań Ludzi Zaginionych, Telefon Zaufania dla Osób Dorosłych w Kryzysie Emocjonalnym oraz Fundacja „Dajemy Dzieciom Siłę”).

7. Szkolenia przygotowujące do działań samopomocowych.

W latach 2016 i 2017 przeprowadzono 12 cykli kilkudniowych szkoleń dla uczestników warszawskich lokalnych placówek wsparcia. Miały one na celu zachęcenie osób po kryzysie psychicznym do podjęcia działań samopomocowych w Grupie Wsparcia TROP. Mające formę warsztatową szkolenie jest w całości przygotowane i prowadzone przez członków Grupy. 
8. Bezpośrednie wsparcie dla osób chorujących i ich rodzin (wizyty w domach).

Trzy osoby z Grupy w razie potrzeby udzielają wsparcia innym chorującym w miejscu ich zamieszkania. Celem działania jest zachęcenie osób po kryzysie do wyjścia z domu i podjęcia aktywności. Jednocześnie jest to forma wsparcia emocjonalnego dla chorych i ich bliskich.

\section{Spotkania integracyjno-szkoleniowe.}

Ich celem jest integracja członków Grupy, zachęcenie innych do wspólnych działań samopomocowych oraz poszerzanie wiedzy przydatnej w trakcie realizacji projektów. W 2017 roku we współpracy z profesjonalistami z APS zorganizowano szkolenie z prezentacji multimedialnych, warsztatów wspierania zdrowia psychicznego. Odbyły się również dwa wyjścia do kina, wizyta w planetarium i wyjście do kawiarni.

10. Punkty konsultacyjne dla osób po kryzysie psychicznym i ich bliskich.

Podstawową ideą programu jest partnerska współpraca profesjonalistów (psychologów i pracowników socjalnych) oraz ekspertów przez doświadczenie w ramach punktów konsultacyjnych. W okresie od sierpnia do listopada 2017 roku w Warszawie dyżurowały trzy takie zespoły. Oferowały one kompleksowe wsparcie i porady dla osób z doświadczeniem kryzysu i ich rodzin. Program stanowi doskonałe uzupełnienie działalności Doradców Telefonicznych.

11. Poradnik - Informator. Jak radzić sobie z kryzysem, znaleźć wsparcie i poszerzać swoje możliwości.

To publikacja przygotowana wspólnie przez członków Grupy i profesjonalistów. Składa się z dwóch części. Pierwsza to poradnik przygotowany przez osoby po kryzysie psychicznym dotyczący sposobów radzenia sobie z chorobą i różnych aspektów leczenia. Część druga zawiera dane teleadresowe instytucji i organizacji wspierających osoby chorujące psychicznie i ich rodziny. Publikacja jest podstawowym narzędziem pracy Doradców Telefonicznych TROP-u, jest regularnie aktualizowana.

\section{2. „Biuletyn TROPiciel”.}

Teksty do „Biuletynu TROPiciel” przygotowywane są wyłącznie przez osoby chorujące. Dotyczą one przede wszystkim doświadczeń w radzeniu sobie z chorobą i spraw związanych z życiem codziennym. Oprócz tekstów publikowane są również wiersze, rysunki i zdjęcia. Czytelnikami są inni chorujący, ich bliscy oraz profesjonaliści. Do chwili obecnej wydanych zostało siedem numerów Biuletynu. 


\section{Perspektywy rozwoju ruchu samopomocowego w Polsce}

Pięcioletnia działalność Grupy Wsparcia TROP pokazuje, że ruch samopomocowy osób z doświadczeniem kryzysu psychicznego również w Polsce jest bardzo przydatny i może odnieść sukces. Analizując genezę powstania i działalność Grupy w minionych latach, można wskazać na pewne szczególnie istotne dla rozwoju samopomocy elementy.

PRZESTRZEŃ. Tym, czego potrzebują osoby z doświadczeniem choroby chcące działać na rzecz innych, jest przede wszystkim przestrzeń. Bardzo o nią trudno - brakuje instytucji, które mogłyby osoby takie wspierać, nie narzucając im własnych oczekiwań; mało jest miejsc, w których można się spotkać w autentycznie neutralnych warunkach. Trudno jest o profesjonalistów chcących udzielać wsparcia i jednocześnie rezygnujących z kierowania grupą osób chorujących. Wspieranie ze strony profesjonalistów powinno więc polegać na tworzeniu przestrzeni i warunków do działania, same pomysły na działanie należy natomiast zostawić grupie. Odwołując się do doświadczeń TROP-u, powinno wyglądać to tak, że jeśli ludzie z doświadczeniem kryzysu chętne do działania zamierzają spotykać się regularnie, to trzeba im pomóc w znalezieniu dogodnego miejsca i nie należy ingerować w przebieg spotkań. Jeśli myślą o prowadzeniu dyżurów telefonicznych, to trzeba znaleźć kompetentne osoby gotowe przeszkolić ich w prowadzeniu porad i omawiania ich przebiegu. Jeśli chcą wydawać biuletyn, to warto zastanowić się nad znalezieniem wolontariusza pomocnego w edycji tekstów. Czyli niezbędne jest zapewnienie możliwie efektywnego wsparcia „technicznego” przy jednoczesnym zachowaniu dystansu co do podejmowania decyzji i określania kierunków działań.

SAMODZIELNOŚĆ. Obecnie w polskich warunkach w świadomości społecznej osoby chorujące psychicznie są niejako utożsamiane z psychiatrią. To skojarzenie jest prawie automatyczne, stąd też pokusa, aby budować ruchy samopomocowe oparte na środowiskach psychiatrycznych. Nie sprzyja to rozwojowi samopomocy, ponieważ osoba z doświadczeniem kryzysu to jednak dla psychiatrii przede wszystkim „pacjent”. Nie jest możliwe, aby diagnozować, przepisywać leki, zatrzymywać wbrew woli w szpitalach i jednocześnie dbać o niezależność i odwoływać się do samodzielności swoich pacjentów. Byłoby to pomieszanie ról. Nie wydaje się, aby ruch samopomocowy musiał być zdecydowanie antypsychiatryczny, choć w innych krajach najczęściej tak właśnie jest. Ważne, żeby był od środowisk psychiatrycznych niezależny.

NIEZALEŻNOŚĆ. Wydaje się, że dla efektywnego rozwoju Grupy duże znaczenie miało wsparcie uzyskiwane ze środowisk całkowicie niezwiązanych z leczeniem. Ważne jest, aby pomoc dla grup docierała z zupełnie innych źródeł. Chodzi więc o to, aby ruch samopomocowy osób z doświadczeniem kryzysu psychicznego korzystał z programów rozwoju dla lokalnych grup aktywistów zupełnie niezwiązanych z problematyką zdrowia psychicznego. TROP przez dłuższy czas korzystał z coachingu zapewnianego przez Biuro 
Obsługi Ruchu Inicjatyw Społecznych Boris, zrealizował również grant z Funduszu Inicjatyw Pozarządowych.

PERSPEKTYWA LOKALNA. Sukces TROP-u wynika w znacznym stopniu z tego, że dostosował on swoje działania do warunków i perspektywy lokalnej. Członkowie Grupy nie angażują się w przedsięwzięcia ogólnopolskie o dużym rozmachu, na planowanie których nie mają wpływu. Możliwość samodzielnego wyboru celów i sposobów działania daje poczucie kontroli i satysfakcję z uzyskanego sukcesu. Być może w przyszłości członkowie Grupy włączą się do tego rodzaju inicjatyw ogólnopolskich, ale obecnie uważają, że jest na to zbyt wcześnie. Mają dużo do zrobienia w mniejszej skali i określone osobiste granice intensywności zaangażowania.

SOJUSZNICY. To określenie powstało podczas spotkania TROP-u, w trakcie którego członkowie Grupy zastanawiali się, jak określić osoby z różnych środowisk udzielające im wsparcia. Ich zaangażowanie jest bardzo istotne, wiele projektów byłoby zdecydowanie trudniejszych do przeprowadzenia. Sojusznicy są niezbędni. Ważne jest jednak, aby towarzyszyli oni w realizacji działań Grupy, pamiętając o ograniczeniach swojej roli i wystrzegając się wpływu na kierowanie jej działaniami.

CIĄGŁOŚĆ I STABILIZACJA. Bardzo ważna jest ciągłość pracy Grupy. W znacznym stopniu wiąże się to z uzyskiwaniem środków na działania. Bez nich nie ma mowy o stabilności pracy. Jednocześnie zbyt wczesne sformalizowanie ruchu (zarejestrowanie stowarzyszenia, uzyskanie osobowości prawnej i pozyskiwanie środków) zwykle generuje problemy utrudniające, a nie wspomagające bieżące działania. Niezbędne jest więc znalezienie partnera $\mathrm{z}$ osobowością prawną, który pomoże w uzyskaniu środków i technicznej realizacji projektów (księgowość, sprawozdawczość, rozliczenia). Musi zarazem utrzymywać życzliwy dystans wobec prowadzonych przez TROP działań merytorycznych.

Reasumując powyższe uwagi, warto podkreślić, że powstanie silnego ruchu samopomocowego osób z doświadczeniem kryzysu psychicznego jest w Polsce bardzo potrzebne. Bez niego postawy społeczne oraz system leczenia psychiatrycznego nie zmienią się szybko. Opieranie inicjatyw i pomysłów na działaniach płynących ze środowiska osób chorujących jest bardzo potrzebne. Ich skuteczność będzie zależała od dostępnej przestrzeni społecznej oraz chronienia niezależności tworzących się dopiero lokalnych ruchów ${ }^{1}$.

1 Więcej informacji o działaniach Grupy Wsparcia TROP: www.czasnaporozumienie.pl;www.facebook.com/WspieramyOsobyChorePsychicznie Adres e-mail:porozumienie@aps.edu.pl. 


\section{Bibliografia}

Anthony W.A. (1993). Recovery from mental illness: The guiding vision of the mental Health Service System in the 1990s.,,Psychosocial Rehabilitation Journal”, 16 (4): 11-23.

Deegan P. (1996). Recovery as a journey of the heart. „Psychiatric Rehabilitation Journal”, 19: 91-97.

Goffman E.(2005). Piętno. Rozważania o zranionej tożsamości. GWP, Gdańsk.

Goffman E. (2011). Instytucje totalne. O pacjentach szpitali psychiatrycznych i mieszkańcach innych instytucji totalnych. GWP, Sopot.

Ion R.M., Beer M.D. (2003). Valuing the past: The importance of an understanding of the history of psychiatry for health care professionals, service users and carers. „International Journal of Mental Health Nursery", 12: 237-242.

Laing R. (1967). The Politics of Experience. Random House, New York.

Lysaker P., Cambell K., Johanessen J. (2005). Hope, awareness of illness, and coping in schizophrenia spectrum disorders. „Journal of Nervous and Mental Diseases”, 193: 287-292.

Omeni E., Barnes M., MacDonald D., Crawford M., Rose D. (2014). Service user involvement: Impact and participation: A survey of service user and staff perspectives. „BMC Health Services Research", 14: 491.

Repper J., Carter T.(2011). A review of the literature on peer support in mental health services. „Journal of Mental Health", 20 (4): 392-411.

Scheff T. (1966). Being Mentally Ill: A Sociological Theory. Aldine, Chicago.

Szasz T. (1960). The Myth of Mental Illness. Harper and Row, New York. 